\title{
Geology Structure Identification Using Pre-Stack Depth Migration (PSDM) Method of Tomography Result in North West Java Basin
}

\author{
Sudra Irawan ${ }^{1} *$, Muhammad Zainuddin Lubis ${ }^{1}$ \\ ${ }^{1}$ Geomatics Engineering Politeknik Negeri Batam, Batam Kepulauan Riau, Indonesia, 29461.
}

* Corresponding author : sudra@polibatam.ac.id

Tel..: +6257-4341-9535; Office: 778-469856 ext: 2510; fax: +62-778-463620

Received: Mar 29, 2017. Revised : 2 May 2017, Accepted: May 28, 2017, Published: 1 June 2017 DOI: 10.24273/jgeet.2017.2.2.297

Abstract

North West Java Basin is a tertiary sedimentary basin which is located in the right of the western part of the Java island. North West Java Basin is geodynamic where currently located at the rear position of the path of the volcanic arc of Java that is the result of the India-Australia plate subduction to the south towards the Eurasian plate (Explanation of Sunda) in the north. Geology structure observation is difficult to be conducted at Quaternary volcanicfield due to the classical problem at tropical region. In the study interpretation of fault structures can be done on a cross-section of Pre-Stack Depth Migration (PSDM) used prayer namely Hardware Key Device, ie Central Processing Unit: RedHat Enterprise Linux AS 5.0, prayer Monitor 24-inch pieces, Server: SGl altix 450/SUSe Linux Enterprise Server 9.0, 32 GB, 32 X 2,6 GHz Procesor, network: Gigabyte $1 \mathrm{~Gb} / \mathrm{s}$, and the software used is paradigm, product: Seismic Processing and Imaging. The third fault obtained in this study in accordance with the geological information derived from previous research conducted by geologists. The second general direction is northwest-southeast direction represented by Baribis fault, fault-fault in the Valley Cimandiri and Gunung Walat. This direction is often known as the directions Meratus (Meratus Trend). Meratus directions interpreted as directions that follow the pattern of continuous arc Cretaceous age to Meratus in Kalimantan.

Keywords: North West Java, Geology structure, Pre-Stack Depth Migration (PSDM), Fault.

\section{Introduction}

Geological structure observation is difficult to be conducted at Quaternary volcanicfield due to the classical problem at tropical region such as intensive erosion, dense vegetation covers, and rough terrain (Pradipta \& Saepuloh, 2016). North West Java Basin is a tertiary sedimentary basin which is located in the right of the western part of the Java island (Fig 1). Proven can produce hydrocarbons, such as Field Jatibarang. This basin has a distribution of land and offshore Serang in west stretches Eastward to Cirebon and consists of Several sub-basins (Noble et al., 1997). Research on seismic previously performed using side scan sonar instruments for Identification seabed for introduction of seismic (Lubis et al., 2017). North West Java Basin is geodynamic currently located at the rear position of the path of the volcanic arc of Java that is the result of the India-Australia plate subduction to the south towards the Eurasian plate (Explanation of Sunda) in the north.
Several tectonic events that have occurred since the Tertiary affect the formation of the structure and patterns of sedimentation in the basin. During the period of Late Cretaceous to Early Eocene, ongoing subduction known as the Meratus subduction on the southern boundary of the Sunda Shelf with fire mountain trails pass through the North West Java Basin (Arpandi \& Patmosukismo, 1975).

The Meratus subduction affects the state geological basin (Gresko et al., 1995). The occurrence of regional metamorphism in the Late Cretaceous, the Paleocene deformation, and volcanism until the Early Oligocene estimated of Maratus subduction-related activities. Metamorphism and magmatism that took place resulted in metamorphic and igneous intrusions are then compiled bedrock in North West Java Basin, while the deformation caused erosion on the appointment and Kala Paleocene. Regional stratigraphy basin of North West Java are presented in Fig 2. 


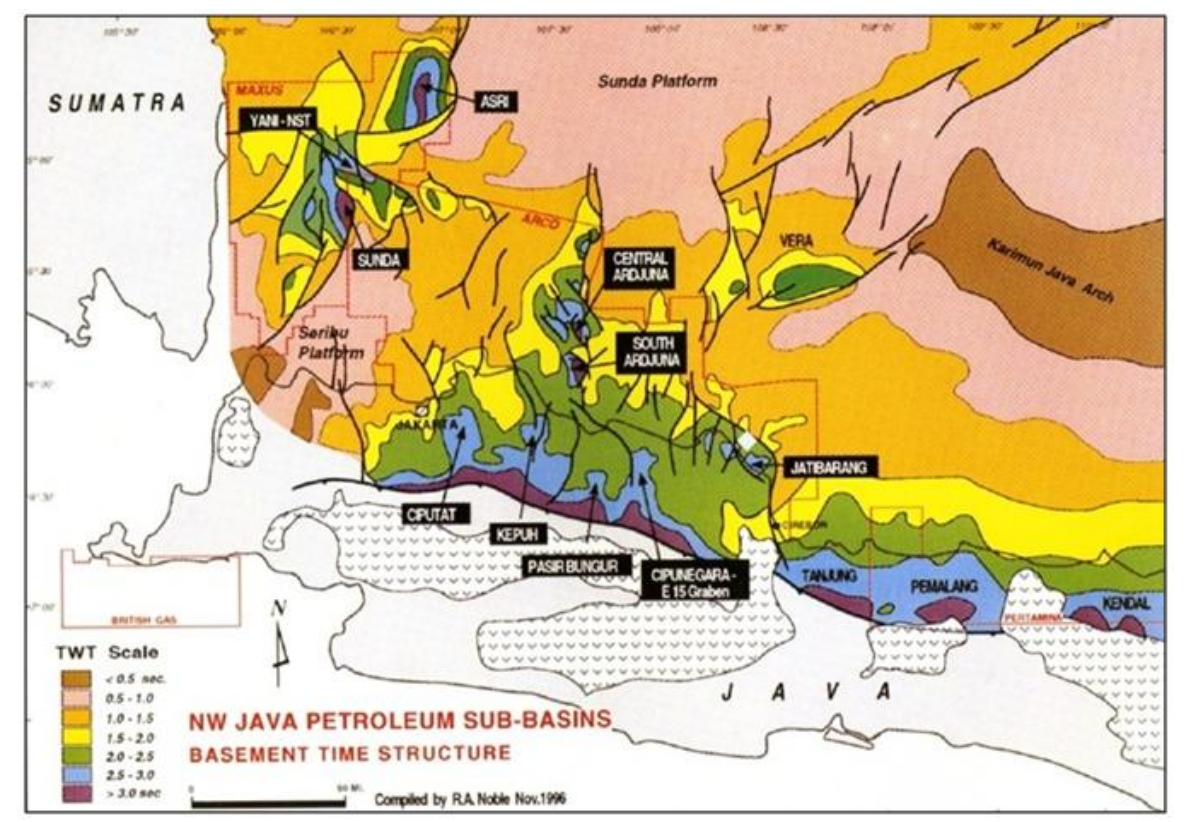

Fig. 1. North West Java Basin (Noble et al., 1997).

Interpretation of fault structures can be done on a cross-section of Pre-Stack Depth Migration (PSDM) the result of improved velocity model with methods Horizon Based Tomography. The Horizon Tomography is a method to correct the error the travel time of seismic waves along the horizon analyzed (Natasia et al., 2016). Improvement in seismic wave propagation time error, then there will be an improvement on the depth error. These improvements are expected to provide the correct information about the subsurface geological conditions (Sudra et al., 2014).

PSDM results obtained in the last iteration of process tomography (accurate velocity models result of improvements) can be used for further seismic activity, namely the interpretation. Subsurface fault identification, estimation of reservoir thickness distribution, and calculation of hydrocarbon reserves is some process of interpretation that can be done on a cross-PSDM.

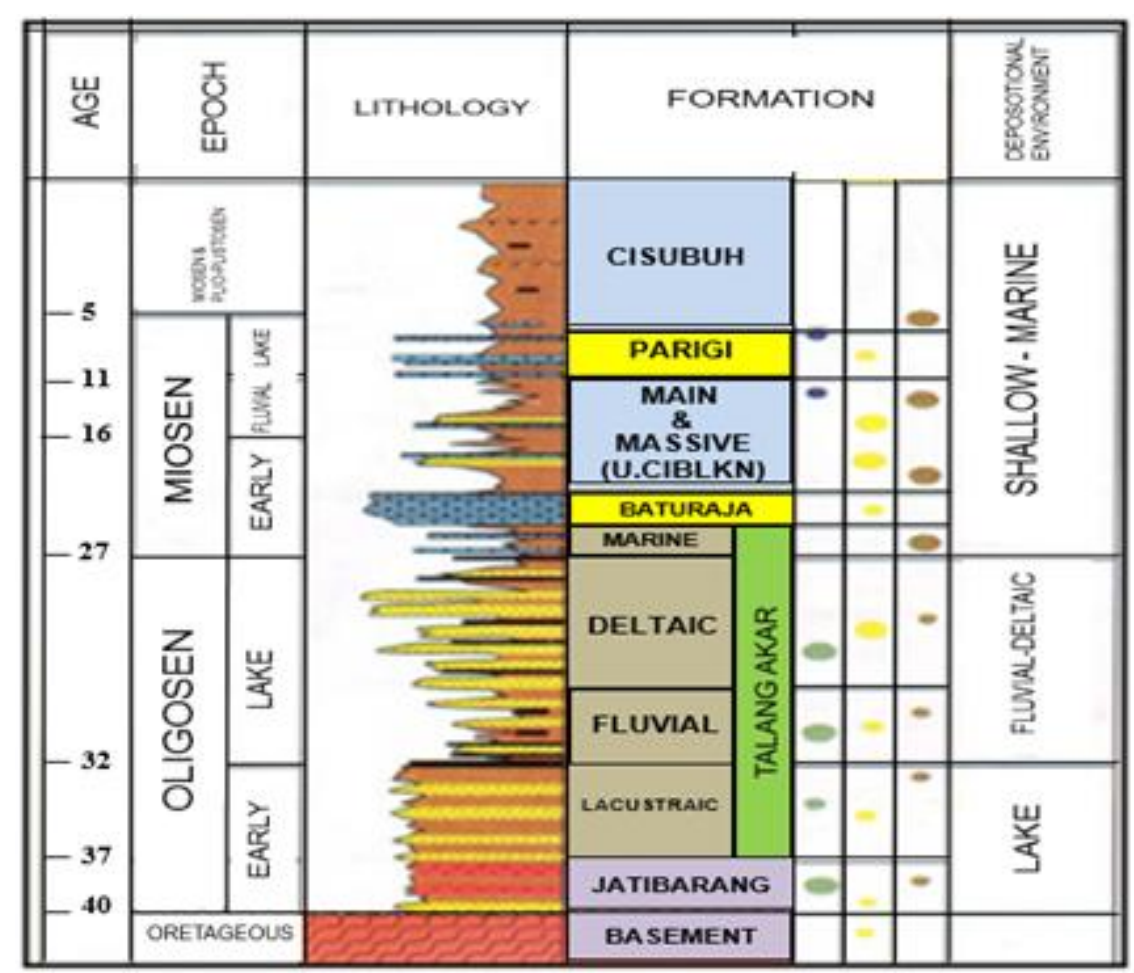

Fig 2. Regional stratigraphy basin of North West Java (Adnan et al., 1991) 
Continuity of reflectors are sharper and can reduce the effects of an excess pull-up imaging resulting from the process PSDM. Image of PSDM results more present than the actual geological model generated imaging PSTM process. The process will be easier because the interpretation of the subsurface domain is already in depth (depth).

Fault or the fault is a fracture zone in the rock that has undergone a shift both vertically and rotated so that the displacement between the parts that deal. The shift of these rocks occur along a surface called the fault plane. Fault was caused by unequal pressure on a layer of rock. The rock will undergo deformation when passing the threshold power of elasticity, these rocks will experience a fault or faults.
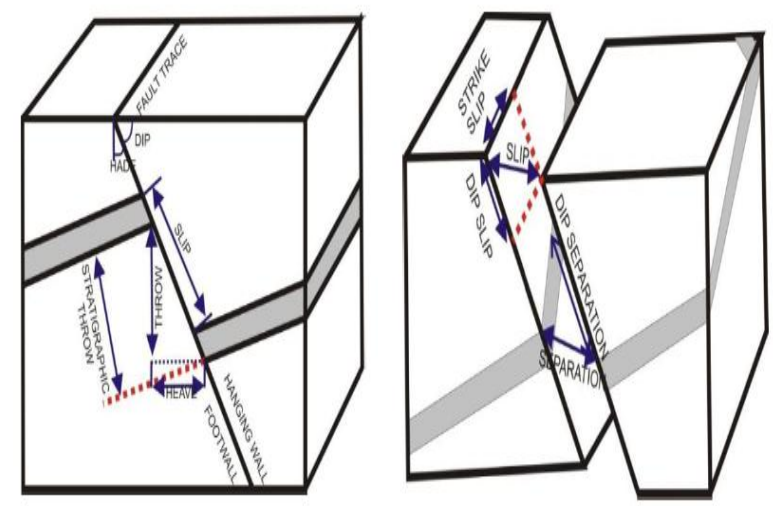

Fig 3. Fault structure (Sheriff \& Geldart, 2002)

Components of fault according to the Sheriff and Geldart (2002) as shown in Fig. 3, consists of: (1) slip is a movement distance relative to one side against the other, (2) throw a vertical component in the field of separation of fault, (3) heave a horizontal component in the field of separation of fault, (4) dip is the angle between the fault plane with the horizontal plane, (5) hade an angle between the fault plane to the vertical plane, and (6) fault trace a fault line on a surface. In principle, any fault on the seismic data indicated by the loss of the seismic event, diffraction, dip changes, and changes in the pattern of events that pass through fault.

\section{Materials and Method}

In the study used prayer namely Hardware Key Device, ie Central Processing Unit: RedHat Enterprise Linux AS 5.0, prayer Monitor 24-inch pieces, Server: SGI altix 450/SuSe Linux Enterprise Server 9.0, 32 GB, $32 \times 2,6 \mathrm{GHz}$ Procesor, network:
Gigabyte $1 \mathrm{~Gb} / \mathrm{s}$, and the software used is paradigm, product: Seismic Processing and Imaging, with details: (1) Software GeoDepth Velocity Modeling (Epos 41), GeoDepth, to perform map-making 3D models and manufacturing RMS velocity and interval velocity model improvements. (2) Software GeoDepth Migrations (Epos 41) (3D K. PSTM (16 CPUs), to run processes and 3D PSTM K. PSDM (Fermat / Eikonal) to run the process PSDM), (3) Software GeoDepth 3D Tomograpy (Epos 4.1) to make the process tomography.

The data consists of two types of seismic data and well data. The seismic data consists of CDP gathers dan RMS velocity and the well data covering: sonic log, density log, resistivity log, gamma log ray (GR), and neutron log. The log data is used to calculate the estimation of hydrocarbon reserves.

The data in this study consists of three main activities, namely to make the map a 3D model RMS velocity as in Fig. 3, making and repairing interval velocity model, and identify subsurface structure of the final PSDM results (Fig 4).

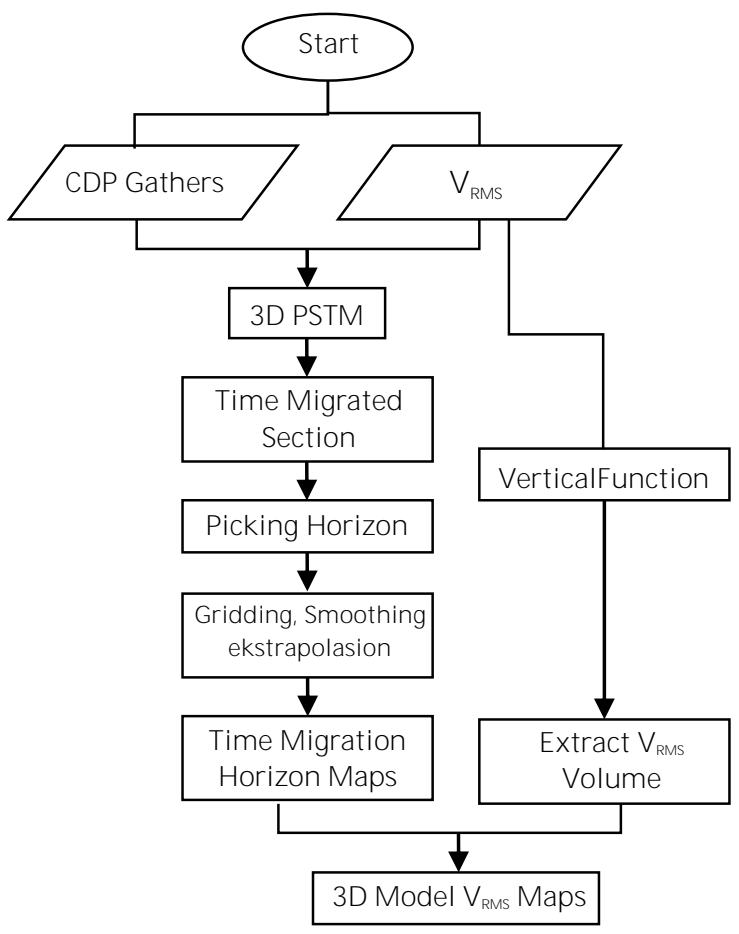

Fig 4. Flow diagram to create 3D model RMS velocity maps 
Identification of the structure in this research focused on the structure of the fault or faults. Sufficient geological knowledge, especially knowledge is the basis of geological structure in identification of the fault. Faulting of PSDM cross section that has been identified, the next dipicking fault, then in the grid so it looks fault field.

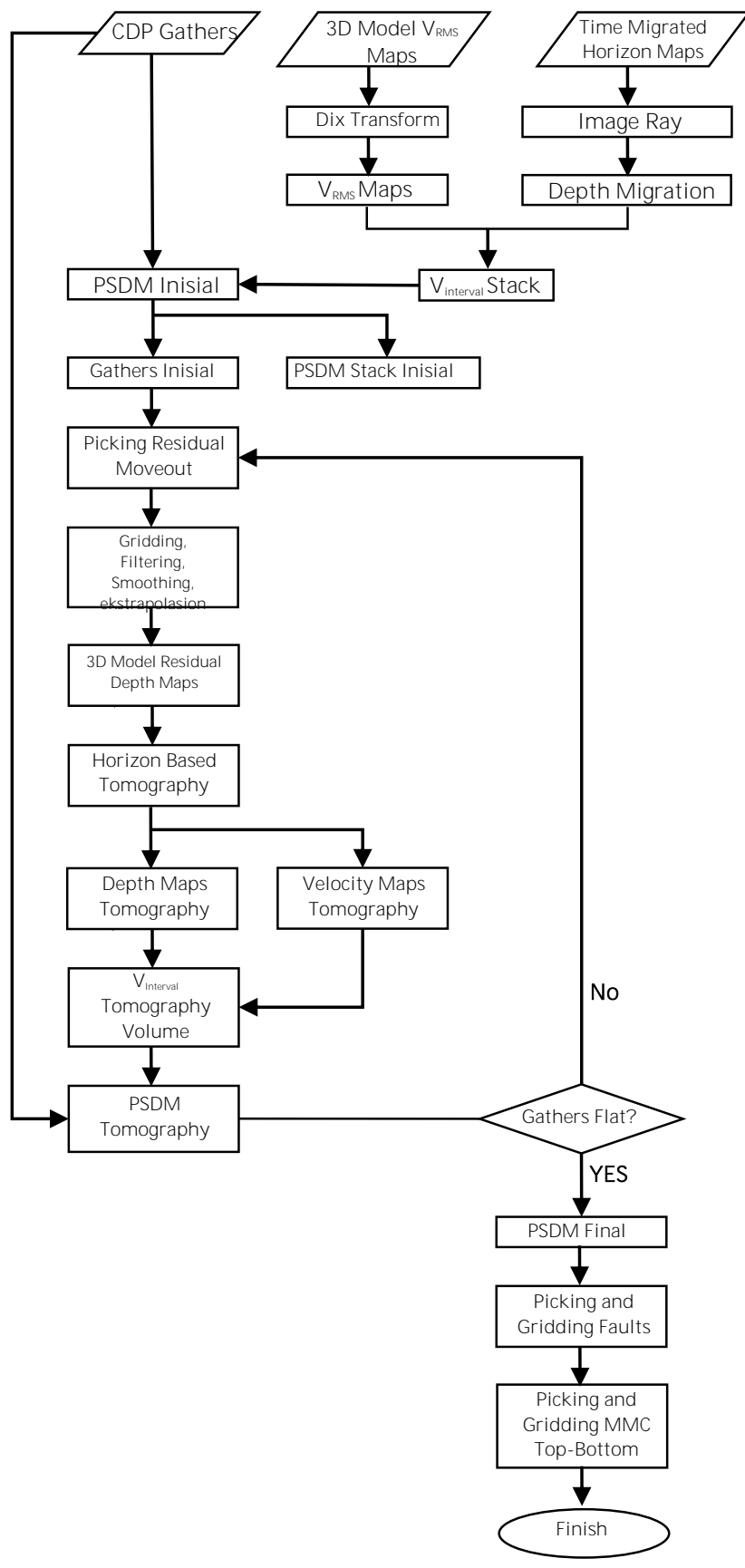

Fig 5. Flow diagram to create and refine the interval velocity model and identify fault structures from final PSDM result.

\section{Result and discussion}

There are three pieces of fault that has been identified from the results of the last tomographic PSDM sesarnya fields (red, blue and purple) shown in Fig 6.

Fault-fault produced already in the depth domain, meaning there are in the depth of the actual fault. 3 pieces fault determination is based on the components of the fault in general that fault plane, tactics (strike) fault, the slope of the fault, the hanging wall, foot wall, slip net (includes trike slip and dip-slip).

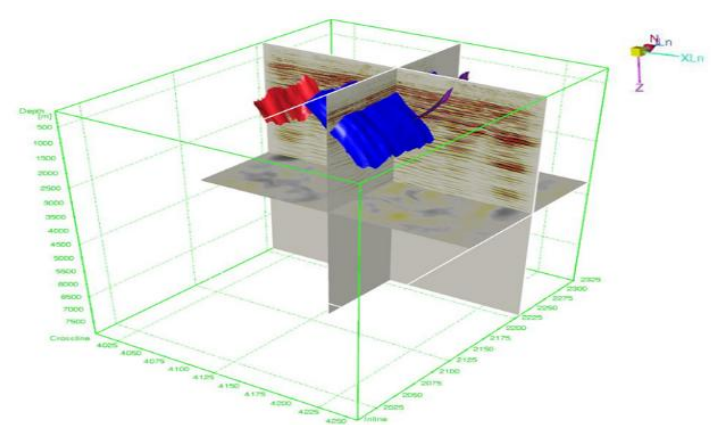

Fig. 6. The three areas of faults were identified in the study area, is included in the third fault normal fault.

The blue color is the fault plane which includes normal fault type (normal fault). Normal fault is a major fault which has a strike direction southwest-northeast. The slope of the fault is estimated at $65^{\circ}$, with the hanging wall and foot wall of fault is shown in Fig. 7. The net value is estimated at around 73 meters slip. Part of the net slip, the strike slip and dip-slip hard to identify from Fig 7.

The red color (Fig 8) is the fault plane of the type of normal faults that have the same strike direction as the major fault is southwestnortheast. This fault means that minor faults included in this fault follows the major fault (main).

The slope of the fault is estimated at $75^{\circ}$, steeper than the main fault. The part of hanging wall and foot wall of this fault is shown in Fig 8. The net value is estimated in around 10 meters slip.

The purple color in Fig 9 is a normal fault of the fault plane which has a strike direction of northwest-southeast, opposite the main fault strike.

Fault is also included in a minor fault with a slope of approximately $75^{\circ}$. The part of hanging wall and foot wall of this fault is shown in Fig 9. The net value is estimated at around 10 meters slip. 


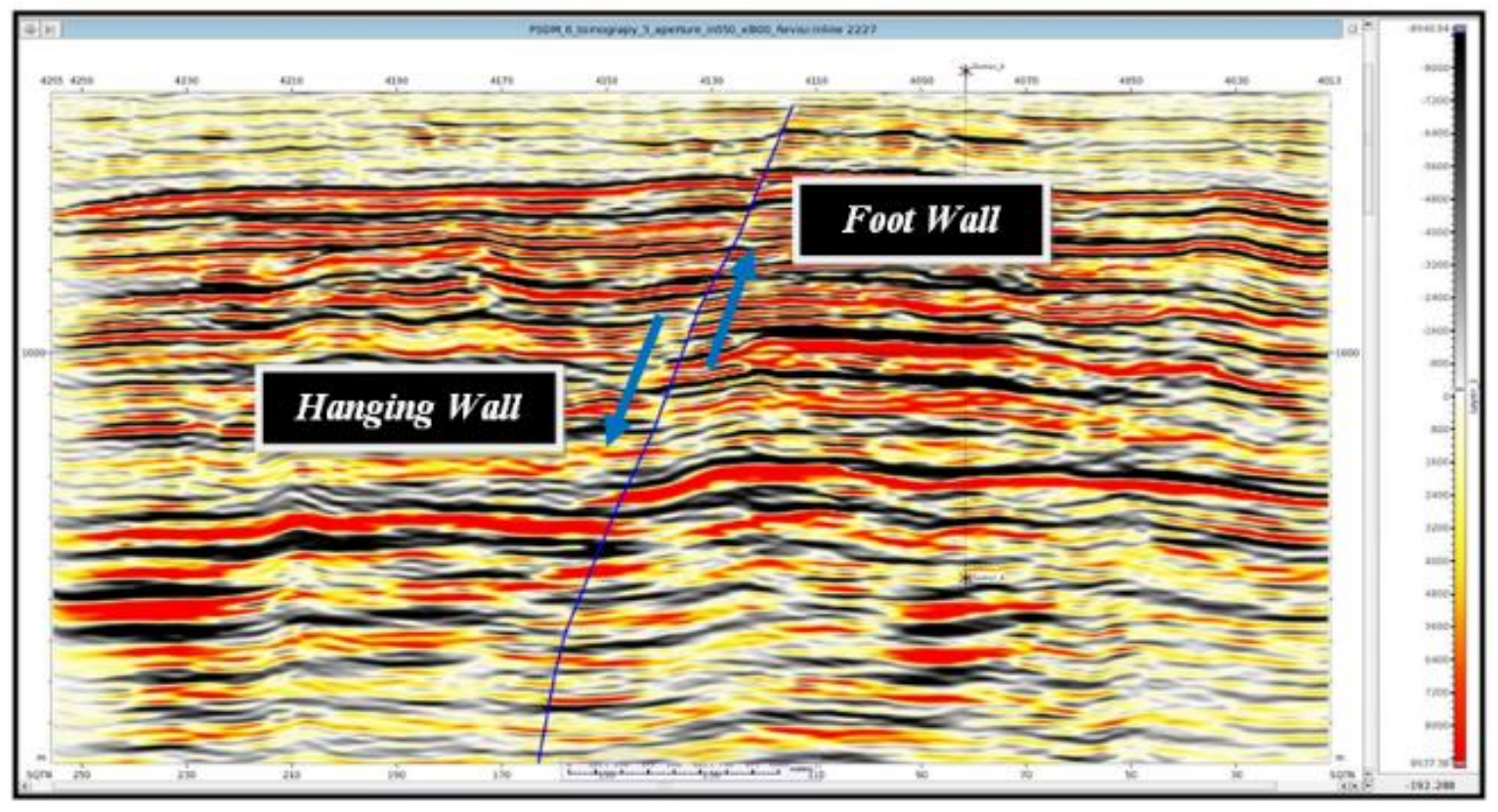

Fig. 7. The appearance of the hanging wall and foot wall on a normal fault (blue) at the cross end PSDM.

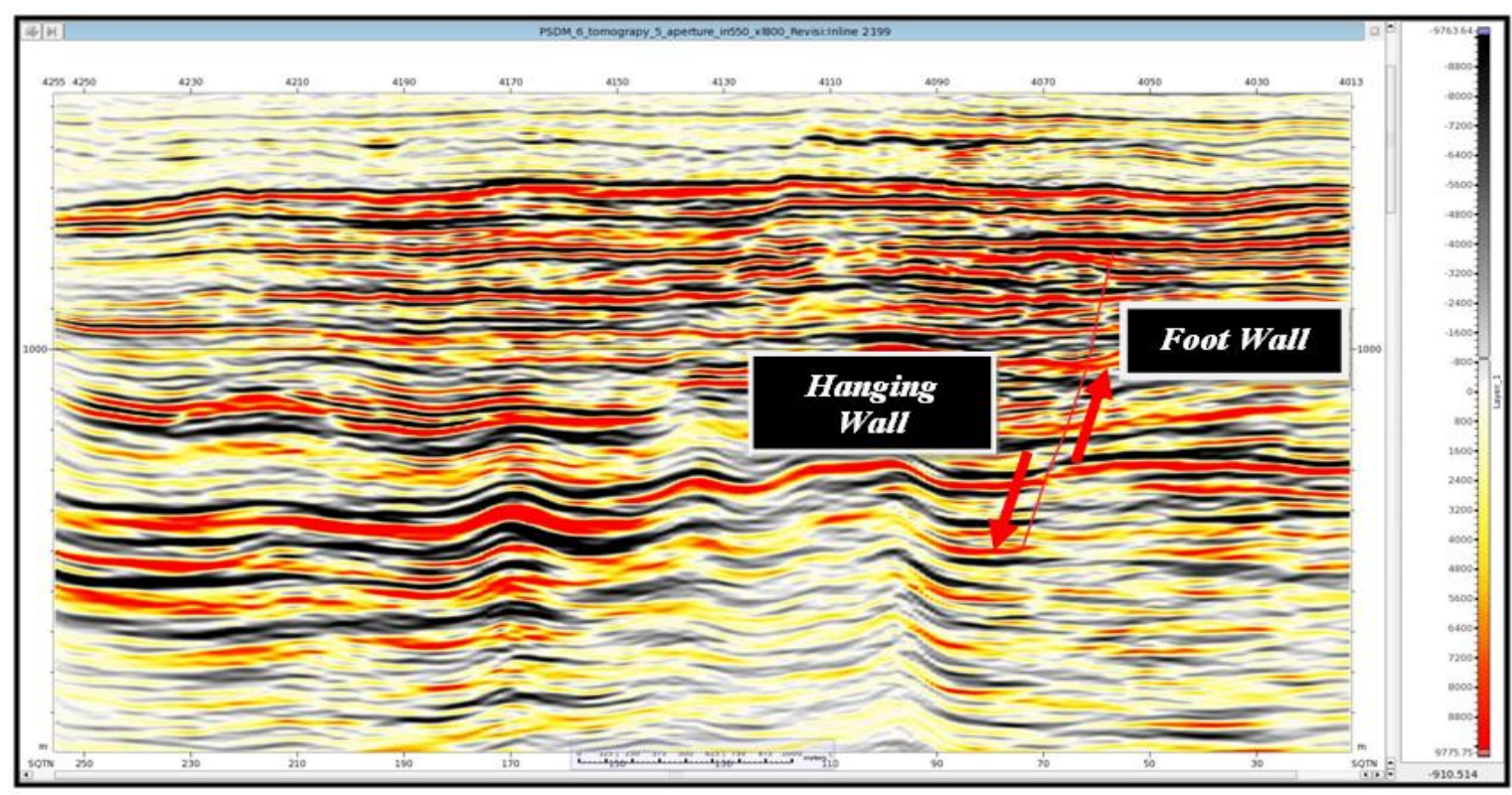

Fig. 8. The appearance of the hanging wall and foot wall on a normal fault (red) in the sectional final PSDM. 


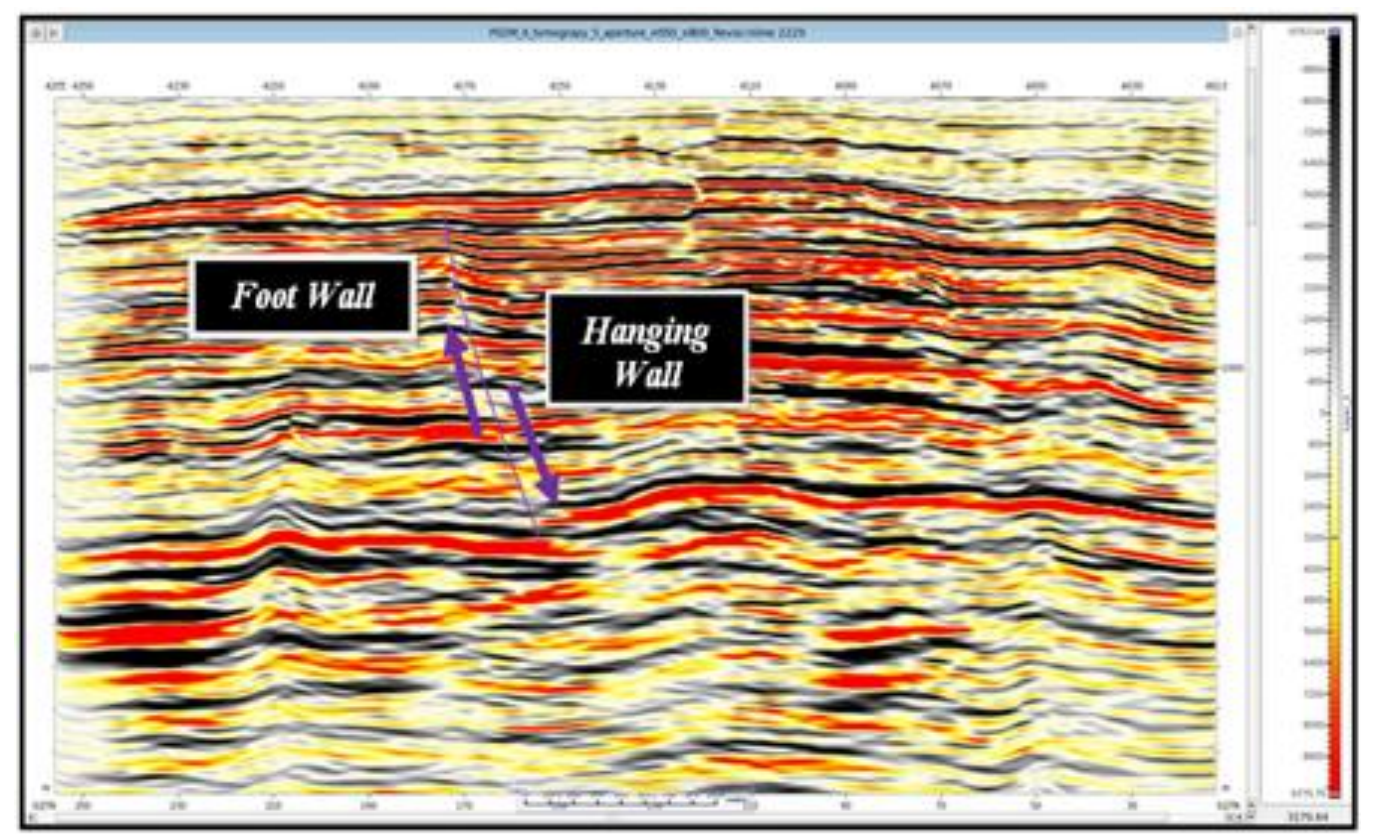

Fig. 9. The appearance of the hanging wall and foot wall on a normal fault (purple) in the sectional final PSDM

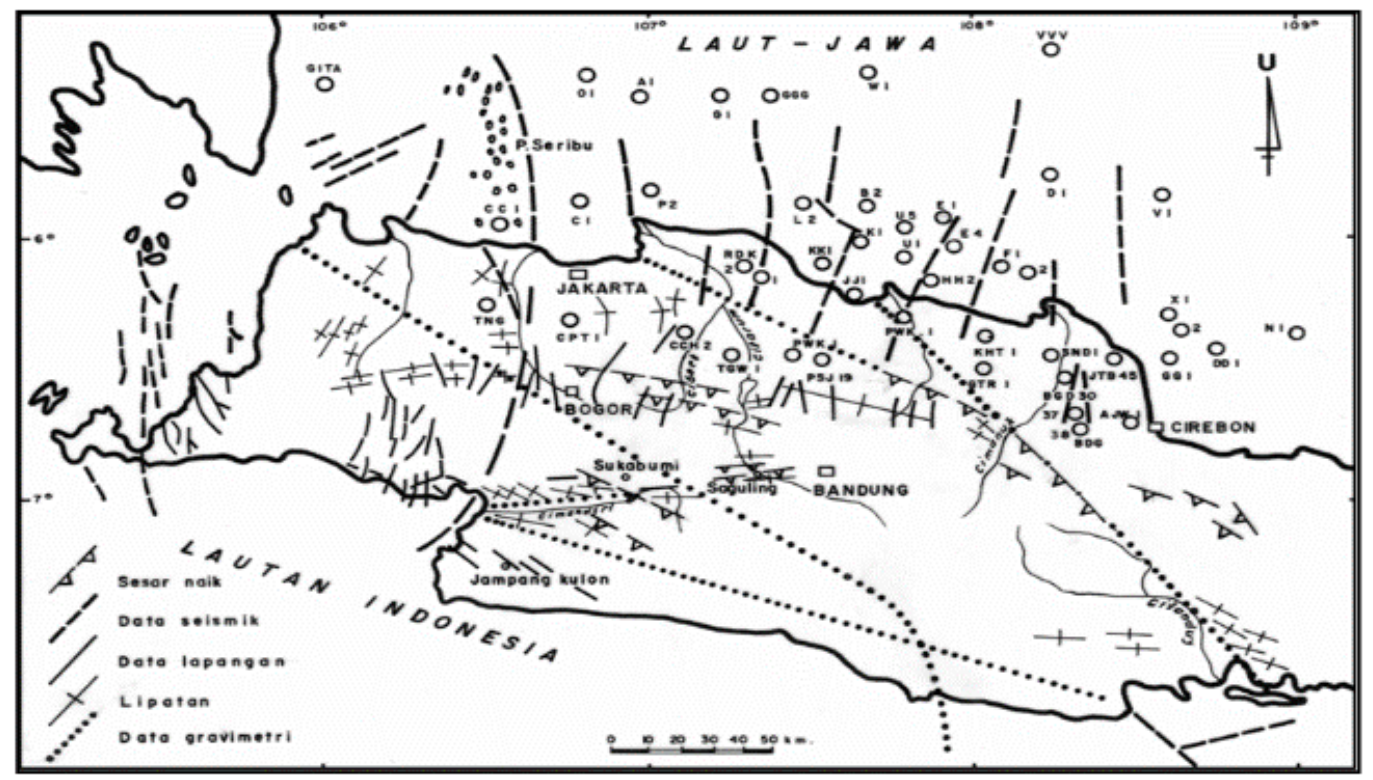

Fig. 10. General Pattern Structures in North West Java Basin (Martodjojo, 2003)

The third fault obtained in this study in accordance with the geological information derived from previous research conducted by geologists. According to Martodjojo (2003), in general faults and folds in the basin of North West Java is divided into three main directions (Fig 10). The first direction is southwest-northeast, which is represented by Cimandiri fault, reverse fault and fault-Rajamandala other faults in the area Purwakarta. This direction is often known as the directions Meratus (Meratus Trend). The Meratus direntions were interpreted as directions that follow the pattern of continuous arc Cretaceous age to Meratus in Kalimantan (Katili, 1978 and Setiawan et al., 2015). Fault corresponding to the first direction in this study is a normal fault in blue and red (Fig 7 and 8 ).

The second general direction is northwestsoutheast direction represented by Baribis fault, faults in the Cimandiri valley and mount Walat. This direction is known as directions Sumatra (Sumatra Trend), as a parallel to the direction of the Bukit Barisan Mountains. Fault that has been identified in accordance with the direction this is normal fault purple color (Fig. 8). The third general direction is north-south direction. These directions are on-mountain Ciletuh straightness Thousand (Fault Cidurian, block Leuwiliang). But in the Sunda Shelf, off the northern coast of West Java, the pattern of this fault is a major pattern. 


\section{Conclusion}

Research in North West Java Basin have third general direction is north-south direction. The third fault obtained in this study in accordance with the geological information derived from previous research conducted by geologists.

\section{References}

Adnan, A., Sukowitono, dan Suprianto., 1991, Jatibarang Sub Basin - A Half Graben Model in the Onshore of Northwest Java, Proceedings of Indonesian Petroleum Association, 20th Annual Convention.

Arpandi D., dan Patmosukismo, S., 1975, The Cibulakan Formation as One of the Most Prospective Stratigrahpic Units in the North West Java Basinal Area, Proceedings of Indonesian Petroleum Association, 4th Annual Convention.

Gresko, M., Suria, C. and Sinclair, S., 1995. Basin evolution of the Ardjuna rift system and its implications for hydrocarbon exploration, offshore Northwest Java, Indonesia.

Katili, J.A., 1978. Past and present geotectonic position of Sulawesi, Indonesia. Tectonophysics, 45(4), pp.289-322.

Lubis, M. Z, Anurogo, W., Khoirunnisa, H., Irawan, O. G., \& Roziqin, A. 2017. Using Side-Scan Sonar instrument to characterize and map of seabed for identification target in punggur sea of the Riau islands. JGEET (JOURNAL OF GEOSCIENCE, ENGINEERING, ENVIRONMENT, AND TECHNOLOGY), 2(1).
Martodjojo, S., 2003. Evolusi Cekungan Bogor Jawa Barat. Penerbit ITB Bandung.

Natasia, N., Syafri, I., Alfadli, M.K., Arfiansyah, K., 2016. Stratigraphy Seismic and sedimentation Development of Middle Baong Sand , Aru Field ,North Sumatera Basin. J. Geoscience, Engineering, Environment, and Technology 1, 51-58.

Noble, R.A., Pratomo, K.H., Nugrahanto, K., Ibrahim, A.M., Prasetya, I., Mujahidin, N., Wu, C.H. and Howes, J.V.C., 1997. Petroleum systems of northwest Java, Indonesia.

Pradipta, R. A., \& Saepuloh, A. 2016. Geology Structure Identification based on Polarimetric SAR (PolSAR) Data and Field Based Observation at Ciwidey Geothermal Field. In IOP Conference Series: Earth and Environmental Science (Vol. 42, No. 1, p. 012008). IOP Publishing.

Setiawan, N. I., Osanai, Y., Nakano, N., Adachi, T., \& Asy'ari, A. 2015. Metamorphic Evolution of Garnet-bearing Epidote-Barroisite Schist from the Meratus Complex in South Kalimantan, Indonesia. Indonesian Journal on Geoscience, 2(3), 139-156.

Sheriff, R.E., 2002. Encyclopedic dictionary of applied geophysics. Society of exploration geophysicists.

Sudra Irawan, Sismanto, \& Adang Sukmatiawan.2014. Applying the Horizon Based Tomography Method to Update Interval Velocity Model, Identify the Structure of PreStack Depth Migration 3D and Estimate the Hydrocarbon Reserve in SBI Field of North West Java Basin. Jurnal Teknologi,69(6), 53-58. 